УДК 81

DOI: $10.17223 / 19986645 / 51 / 4$

\title{
E.В. Муравенко
}

\section{ГЛАГОЛЫ СО ЗНАЧЕНИЕМ УПРАВЛЕНИЯ: УТРАТА ПЕРЕХОДНОСТИ}

\begin{abstract}
Прослеживаются грамматические изменения в группе глаголов со значением управления - управлять, руководить, предводительствовать, командовать, заведовать, помыкать, править - за последние три века. У этих глаголов управление винительным падежом сменилось управлением творительным, тем самым глаголы утратили переходность. Однако формы пассива, особенно пассивные причастия, сохраняются в языке дольше, чем возможность личных глагольных форм иметь прямое дополнение, и свидетельствуют о былой переходности глагола.

Ключевые слова: изменение глагольного управления, переходность, пассивный (страдательный) залог, пассивная конструкция, пассивное (страдательное) причастие.
\end{abstract}

Одним из трёх синтаксических объектов, исследованием которых занималась В.А. Белошапкова, было словосочетание. При рассмотрении словосочетания не последнее место занимали вопросы, связанные с историческими изменениями в составе словосочетания и в поведении главного и зависимого слов (см., например, главу об изменении субстантивных словосочетаний в коллективной монографии [1]). Данная статья продолжает это направление: она посвящена изменениям в глагольных словосочетаниях.

$\mathrm{C}$ течением времени у многих глаголов изменяется управление: предложное управление может замениться беспредложным с тем же падежом (писать к кому $\rightarrow$ писать кому, вкусить от чего $\rightarrow$ вкусить чего) или, наоборот, к управляемой форме без предлога может добавиться предлог (дотронуться чего $\rightarrow$ дотронуться до чего, избавиться чего $\rightarrow$ избавиться от чего), может поменяться предлог при сохранении падежа (отнять om кого $\rightarrow$ отнять у кого), предложное управление может замениться формой другого падежа с предлогом (nосnорить за что $\rightarrow$ nocnopumb $o$ чем) или формой другого падежа без предлога (интересоваться о чем $\rightarrow$ интересоваться чем, предать на суд $\rightarrow$ предать суду), может и беспредложное управление замениться предложным с другим падежом (обижаться чем $\rightarrow$ обижаться на что).

Особые случаи - глаголы с изменившимся управлением, где этими изменениями была затронута форма винительного падежа без предлога, т.е. либо она заменилась другой формой, либо другая форма была заменена формой винительного падежа. Здесь помимо изменения в управлении мы сталкиваемся с изменением признака переходности глагола: переходные 
глаголы становятся непереходными, а непереходные - переходными, т.е. изменения в синтаксисе сопровождаются изменениями в морфологии.

Случаи появления признака переходности (например, укорять кому $\rightarrow$ укорять кого) не столь многочисленны, тогда как обратное явление - утрата глаголом переходности - представлено в языке довольно широко. Прежнее прямое дополнение у разных глаголов могло заменяться на дополнение в косвенном падеже без предлога (угрожать кого / что $\rightarrow$ угрожать кому / чему) или с предлогом (отомстить кого $\rightarrow$ отомстить за кого) или просто утрачивалось (ликовать что $\rightarrow$ ликовать).

В данной статье остановлюсь на группе глаголов, у которых за последние три века (с начала XVIII в. по настоящее время) прямое дополнение сменилось дополнением в творительном падеже: управлять, руководить, предводительствовать, командовать, заведовать (заведывать), помикать, править.

Как видно из примеров, эти глаголы имеют значение управления, руководства. Изменения в языке происходят непрерывно, поэтому, чтобы лучше понять особенности названного периода, обратимся ненадолго к более древнему состоянию языка. Т.П. Ломтев отмечал, что «в древнерусском языке винительный падеж употреблялся для обозначения объекта владения, управления, руководства со стороны субъекта» [2. С. 260]. Что касается глаголов владения, винительный сменился творительным (точнее, из возможных вариантов победил творительный) уже в древнерусском языке (см. о переходном и непереходном употреблении глаголов обладания владеть и обладать в монографии В.Б. Крысько [3. С. 9, 188, 416]). Один пример с глаголом владеть в переходном употреблении, правда, можно найти в текстах XVIII в. в НКРЯ [4]: Сколько давно владеет он деревню тую, Крепость имеет или грамоту какую (А.Д. Кантемир. 1731). Но это лишь остатки устаревшего к тому времени употребления.

Глаголы же со значением управления и руководства дольше сохраняли управление винительным падежом. Т.П. Ломтев в работе [3. С. 260] приводит примеры глаголов править и управлять с винительным объекта управления у писателей XVIII в. Исследователи истории языка, изучавшие изменением управления глаголов XIX в., отмечали, в частности, замену винительного творительным у глаголов править [5. С. 346; 6. С. 339], управлять [5. С. 346], руководить [6. С. 340; 7. С. 215-216].

Однако подробного описания грамматических изменений в глаголах данной группы и даже полного перечня глаголов данной группы ни в одном исследовании найти не удалось, поэтому представляется, что данная статья заполнит небольшую лакуну в описании грамматических изменений. В наши дни, используя такой мощный инструмент, как НКРЯ [4], можно попытаться более точно установить временные границы изменения управления и форм разных глаголов.

Случай с изменением переходности более сложный, чем другие случаи изменения управления, ведь переходные глаголы в отличие от непереходных могут образовывать пассивную конструкцию и обладают формами 
пассивных причастий. Как правило, у таких глаголов не все прежние пассивные формы исчезают. В результате возникают глаголы с избыточными парадигмами.

Тем самым в современном языке есть признаки, по которым мы можем догадаться о прежних, ныне утраченных, признаках глагола: наличие форм пассивного залога свидетельствует о былой переходности (самолёт управляется пилотом; самолёт, управляемый пилотом).

Вопрос о наличии пассивных причастий у непереходных глаголов стоит обсудить отдельно. В ряде исследований, характеризующих грамматические изменения глаголов в XIX в., указывается, что некоторые авторы образуют пассивные причастия от непереходных глаголов (см., например, [6. С. 127; 8. С. 474]). Правда, Л.А. Булаховский замечает, что из приведённых им примеров часть «относится к случаям старинного управления винительным падежом, позже вытесненного другими конструкциями» [6. С. 127]. Наблюдения с помощью НКРЯ показывают, что если в языке XIX-XXI вв. используются пассивные причастия от непереходного глагола, это означает, что глагол раньше был переходным и, по-видимому, причастия не образуются авторами каждый раз заново от глагола - авторы просто используют готовые формы, сохранившиеся с более ранних времён и продолжающие функционировать в языке. При этом функционирование пассивных причастий может длиться десятки и даже сотни лет после утраты переходного употребления личными формами глагола.

Мой вывод, сделанный с помощью НКРЯ, находит подтверждение в монографии В.Б. Крысько. Он пишет, что пассивные причастия свободно образовывались от непереходных глаголов лишь в древнерусском языке [3. С. 415-420], «в последующие периоды русской языковой истории описанные феномены в основном сокращают свое употребление» [3. С. 420421], а «к началу XIX в. причастный пассив стал соотноситься уже только с транзитивными невозвратными глаголами ...» [3. С. 423]. В современном литературном языке единственным примером образования пассива от непереходных глаголов В.Б Крысько считает исключительно случай «со страдательными конструкциями, синхронно соответствующими сочетаниям с ТП при глаголах владения и руководства (руководимое им учреждение, предводительствуемое им войско, управляемая им губерния)» [3. С. 423-424], что обусловлено «полным функционально-семантическим сходством ТП в таких оборотах с вытесненной им исконной формой управления - ВП прямого объекта» [3. С. 424]. Рассматриваемые в данной статье глаголы относятся именно к этой группе. Я не могу согласиться с В.Б. Крысько только в том, что эта группа единственная (см., например, современные причастия благодетельствуемый, покровительствуемый, достигнутый, отмщённый, польщеённый), но это уже не относится к теме данной статьи.

Глаголы со значением управления и руководства утрачивают переходность, однако семантические роли управляемых актантов остаются прежними, просто в современном языке пациенс при этих глаголах выражается 
уже не винительным, а творительным падежом (о различении собственно переходности, или транзитивности, и объективности, т.е. лексикосемантической переходности, см. [3. С. 9]).

Остановлюсь подробнее на каждом из глаголов этой группы.

\section{Управлять}

Этот глагол из всего заявленного списка наиболее близок к переходным глаголам, поскольку у него до сих пор сохраняется не только пассивное причастие управляемыци, но и личные формы пассивного залога: Но это возможно только в тех случаях, когда объект управляется двигателем (Владимир Губарев и др. 2008); В ФРГ значительная часть предприятий управляется наблюдательньли советами (Валерий Андреев. 2004).

Пассивные формы этого глагола настолько распространены и естественны, что иные авторы учебников для иностранцев, вводя формы пассивных причастий, даже не замечают особенностей этого глагола и рассматривают его среди переходных, включая в соответствующие упражнения, в результате учащиеся неизбежно делают ошибки, порождая по образцу фразы типа Космонавт управляет космический корабль...

Небольшая лингвистическая задачка, в которой требовалось указать, какие из трёх причастий - возглавляемый, управляемыцй, руководимый образованы с отклонением от общего правила, поставила в тупик абсолютное большинство школьников, студентов и более взрослых людей с высшим образованием: всем кажется, что все три причастия образованы одинаково правильно. Значит, причастие управляемый (как и руководимылй) воспринимается совершенно естественно. Пассивное причастие управляемыци, а также возможность образования личных форм пассивного залога указываются в современных словарях [9-11].

Между тем личные формы глагола управлять с прямым дополнением сохраняются лишь до начала XIX в.: Кто вел его на Геликон / И управлял его шаги? (Г.Р. Державин. 1805).

Управление же творительным падежом достаточно регулярно начинает использоваться с 30-х гг. XVIII в., а первый пример из НКРЯ с управлением творительным падежом относится к 1709 г.: А артиллериею управлял генерал-порутчик от артиллерии Брюс («Обстоятельная реляция» о Полтавской битве. 1709); Народами той же Разум управляет, / Преступаюших же с злочинств достягает, / Он иарства правит (А.Д. Кантемир. 1731-1740); Марс сечется за тебя, войском управляя (А.П. Сумароков. 1739).

Таким образом, в течение всего XVIII в. наблюдается вариативное управление, а с начала XIX в. побеждает управление творительным падежом. Видимо, к началу XIX в. творительный объекта при этом глаголе был

\footnotetext{
${ }^{1}$ См., например, упражнения 3 на с. 69 или 5 на с. 70 из учебника русского языка (первый уровень - I) «Дорога в Россию» В.Е. Антоновой, М.М. Нахабиной, А.А. Толстых (3-е изд. СПб.; М., 2009).
} 
уже настолько более естествен, чем винительный, что употреблялся даже тогда, когда рядом оказывалась форма в творительном падеже с другим значением (инструментальным): Сенатом управлять державною рукою, / Сражаться с вихрем бед и грозною судьбою, / Обилье, счастие на смертных проливать, / В слезах признательных дела свои читать - / Сего их рок лишил своим определеньем! (В.А. Жуковский. 1801).

В словарях, отражающих язык XIX в. [12, 13], указывается управление только творительным падежом. Ф.И. Буслаев для современного ему языка (середины XIX в.) также указывает творительный падеж, но пишет, что в древности глагол использовался с винительным падежом и что «это управление удерживалось в народной словесности до позднейшего времени», приводя пример 1724 г. $^{2}$ [5. С. 346].

Управление отглагольного существительного со значением действия дольше сохраняет признаки переходности производящего глагола. Так, родительный падеж при существительных, характерный в случае переходных глаголов, употребляется до 30-Х гг. ХІХ в.: Вступив в управление имения, Иван Петрович, по причине своей неопьтности и мягкосердия, в скором времени запустил хозяйство... (А.С. Пушкин. 1830); Сменив исправного и расторопного старосту, коим крестьяне его (по их привычке) были недовольны, поручил он управление села старой своей ключнице... (А.С. Пушкин. 1830).

Творительный падеж при существительных встречается в НКРЯ с 1745 г.: Мнение об управлении юртовскими татарами и о разверстании земель между ними (В.Н. Татищев. 1745). Таким образом, период вариативного управления при отглагольном существительном длился примерно 85 лет. Для середины периода вариативности характерно использование обоих падежей в той же функции в одном и том же тексте: Филипп поручил управление Голландии Вильгельму Нассау, приниу Оранскому; Отец ныне владеющего короля, по восстановлении штатгалтерства, вступил в управление Голландиею (Н.А. Бестужев. Записки о Голландии 1815 года. 1821).

Представлю для наглядности данные о грамматических изменениях глагола управлять в таблице:

\begin{tabular}{|c|c|c|c|c|c|c|}
\hline $\begin{array}{c}\text { УПРАВ- } \\
\text { ЛЯТЬ }\end{array}$ & $\begin{array}{c}\text { Управле- } \\
\text { ние лич- } \\
\text { ных форм }\end{array}$ & $\begin{array}{c}\text { Период } \\
\text { вариатив- } \\
\text { ного } \\
\text { управле- } \\
\text { ния лич- } \\
\text { ных форм }\end{array}$ & $\begin{array}{c}\text { Управление } \\
\text { отглагольного } \\
\text { существи- } \\
\text { тельного со } \\
\text { значением } \\
\text { действия }\end{array}$ & $\begin{array}{c}\text { Период вари- } \\
\text { ативного } \\
\text { управления } \\
\text { отглагольного } \\
\text { существи- } \\
\text { тельного }\end{array}$ & $\begin{array}{c}\text { Личные } \\
\text { формы } \\
\text { пассивно- } \\
\text { го залога } \\
\text { наст. вр. }\end{array}$ & $\begin{array}{c}\text { Пассив- } \\
\text { ное при- } \\
\text { частие } \\
\text { управляе- } \\
\text { мылй }\end{array}$ \\
\hline $\begin{array}{c}\text { Признаки } \\
\text { переход- } \\
\text { ности }\end{array}$ & $\begin{array}{c}\text { Вин. па- } \\
\text { деж до } \\
\text { начала } \\
\text { XIX в. }\end{array}$ & \multirow{2}{*}{$\begin{array}{c}\text { Примерно } \\
100 \text { лет } \\
\text { (в течение } \\
\text { всего } \\
\text { XVIII в.) }\end{array}$} & $\begin{array}{c}\text { Род. падеж } \\
\text { до } 30-\mathrm{x} \text { гг. } \\
\text { XIX в. }\end{array}$ & \multirow{2}{*}{$\begin{array}{c}\text { Примерно } 85 \\
\text { лет с середи- } \\
\text { ны XVIII в. } \\
\text { до 30-х гг. } \\
\text { XIX в. }\end{array}$} & $\begin{array}{c}\text { Употреб- } \\
\text { ляются } \\
\text { до наст. } \\
\text { времени } \\
\end{array}$ & $\begin{array}{c}\text { Употреб- } \\
\text { ляется до } \\
\text { наст. вре- } \\
\text { мени }\end{array}$ \\
\hline $\begin{array}{c}\text { Признаки } \\
\text { непере- } \\
\text { ходности }\end{array}$ & $\begin{array}{c}\text { Твор. } \\
\text { падеж } \\
\text { с } 1709 \text { г. }\end{array}$ & & $\begin{array}{c}\text { Твор. падеж } \\
\text { с } 1745 \text { г. }\end{array}$ & & - & - \\
\hline
\end{tabular}

${ }^{2}$ В НКРЯ есть более поздний пример 1805 г., см выше. 
На примере глагола управлять ясно видно, что утрата переходности происходит постепенно не только потому, что довольно длительное время возможно вариативное управление личных форм, но и сами признаки переходности утрачиваются постепенно: сначала меняется управление личных форм, затем - управление отглагольного существительного со значением действия, дольше всего удерживают свои позиции формы пассивного залога, особенно пассивное причастие.

В той же последовательности происходят изменения и у других глаголов данной группы, разница лишь во временных рамках.

\section{Руководить (и руководствовать)}

Глагол руководить отсутствует в словарях $[12,13]$, не встречается он и в исторической грамматике Ф.И. Буслаева [5]. Однако в этих трех источниках есть глагол руководствовать, который появился в русском языке раньше (первый пример из НКРЯ 1762 г.).

Глагол руководствовать в течение всего времени своего существования в языке мог управлять как винительным, так и творительным падежом объекта. Ф.И. Буслаев [5. С. 347] указывает возможность троякого управления: 1) кого, что; 2) кем, чем и 3) кому для указания на отношение к лицу. Действительно, в НКРЯ среди примеров XVIII в. достаточно примеров и с дательным падежом в значении 'помогать, способствовать', отдельные примеры с дательным встречаются и в XIX в. Кроме того, в XVIII в. также употреблялась конструкция руководствовать кого к чему. В текстах Пушкина глагол руководствовать встречается дважды: по одному разу с винительнм и творительным падежами: Отеи её, никогда не читавший ничего, кроме Совершенной Поварихи, не мог руководствовать её в выборе книг (А.С. Пушкин. 1833); Лев Сергеевич очень себя дурно ведет. <..> Соболевский им руководствует, и что уж они делают, то господь ведает (А.С. Пушкин. 1834).

Глагол руководствовать с пометой устар. есть в словарях [10] и [11], он активно употреблялся с вариативным управлением (вин. и твор.) вплоть до 20-х гг. ХХ в., а отдельные примеры встречаются и во второй половине ХХ в.: Только вам придется руководствовать меня, а то ведь с голодухи можсно и дряни наглотаться (Юлий Даниэль. 1966-1970); А Митька Пенкин - это он Марусей руководствовал - смеется: - Эх ты, хлебороб! (Г. Радов. 1956).

Глагол руководствовать употреблялся в значении 'направлять, наставлять кого-л.', в качестве объекта выступают либо названия лиц, либо слова, метонимически заменяющие название лица (сердие, совесть), либо обозначения действий лиц (поступки, дела, выбор) - в последнем случае чаще используется творительный падеж: руководствовать выбором девушки, но при изменении диатезы - винительный: руководствовать девушку в её выборе. Значение же 'управлять, заведовать' встречается лишь в нескольких примерах 20-х гг. ХХ в. 
Глагол руководствовать был вытеснен глаголом руководить. Это вытеснение происходило постепенно: до 1820 г. глагол руководить практически не использовался, с 20-х гг. до середины века глаголы используются одинаково часто, с середины XIX в. употребление руководствовать резко сокращается и с $20-\mathrm{x}$ гг. XX в. практически сходит на нет, тогда как глагол руководить употребляется всё чаще и чаще. В течение почти столетия (примерно с 30-х гг. XIX в. до 20-х гг. XX в.) глаголы сосуществовали как синонимичные и оба имели вариативное управление винительным и творительным падежами.

В таблице показано, как происходило вытеснение глагола руководствовать глаголом руководить ${ }^{3}$.

\begin{tabular}{|l|c|c|l|}
\hline \multicolumn{1}{|c|}{ Годы } & руководствовать & руководить & \multicolumn{1}{|c|}{ Употребление } \\
\hline До 1820 & 127 & 5 & Руководить - в 25 раз реже \\
\hline $1821-1850$ & 57 & 53 & Одинаково \\
\hline $1851-1900$ & 61 & 1080 & Руководить - в 18 раз чаще \\
\hline $1901-1920$ & 10 & 1349 & Руководить - в 135 раз чаще \\
\hline C 1921 & 34 & 10553 & Руководить - в 310 раз чаще \\
\hline
\end{tabular}

Глагол руководить появился в русском языке довольно поздно. В НКРЯ находятся только два примера XVIII в. с глаголом руководить, приведу один из них: Это всего лишь штрихи, но пером, которое начертало их, признаюсь, руководило сердие (А.М. Шумлянский. 1783). Пять примеров с начала XIX в. до 30-х гг., а после 30-х гг. XIX в. глагол употребляется довольно часто. В XX в. у глагола руководить развивается и второе, более официальное значение: 'заведовать, управлять', которое в XIX в. использовалось редко (этот факт отмечается и в [7. С. 215]).

Винительный падеж с глаголом руководить был возможен до конца XIX в.: Вронский обязан был руководить его в том и в другом (Л.Н. Толстой. 1878); $Я<\ldots>$ так хорошо все потрафлял, что даже вовсе не требовал, чтобы меня, как всех прочих, руководил протодьякон (Н.С. Лесков. 1894).

Итак, в течение почти всего XIX в. у глагола руководить наблюдается вариативное управление винительным и творительным падежами, однако налицо преимущественное использование винительного с одушевлёнными объектами, тогда как творительный используется для таких слов: (руководить) постройкой, наступлением, стремлениями, мыслями, чувствами, действиями, побуждениями, поступками. В.М. Филиппова также замечает, что «в словосочетаниях, имеющих форму с творительным падежом, второй компонент - чаще отвлечённое существительное» [7. С. 216].

С конца XIX в. побеждает творительный падеж для объектов с любым значением. В современных словарях указывается только управление тво-

\footnotetext{
${ }^{3}$ Абсолютное число употреблений в НКРЯ за какой-то период нельзя сравнивать с числом употреблений в другой период, поскольку количество текстов в разные периоды представлено разное (чем ближе к нашему времени, тем больше текстов). Однако относительные величины вполне подлежат сравнению (см. последний столбец таблицы).
} 
рительным падежом, в [10] и [11] приводится также управление винительным падежом как устаревшее.

Личные формы пассивного залога употреблялись до конца 30-х гг. XX в. В словаре Ушакова [11] (1939 г.) указывается возможность образования пассивного залога (руководиться) с пометой «редко». Пример из НКРЯ: По городу полетел слух, что все эти беспорядки кем-то руководятся (А.Н. Толстой. 1922). Отдельные употребления встречаются вплоть до настоящего времени: Bы правильно заметили в вашем письме: "До коей поры московская партийная организация будет руководиться, сама того не понимая, из Мюнхена?» (Евгений Евтушенко. 1999).

Пассивное же причастие руководимый до сих пор фигурирует в словарях (см. [9, 11]) и текстах: Клавдия Васильевна - это К. В. Рождественская, редактор и писательница, работавшая некоторое время в редакции, руководимой Маршаком, а затем уехавшая из Ленинграда в Пермь (Аркадий Мильчин. 2001).

\section{Предводительствовать}

Уже в XVIII в. преобладало управление творительным падежом: Кловис, предводительствуя римскою армиею, принят был галлами как искусный политик и счастливый победитель (Д.И. Фонвизин. 1764-1766). В [12] указан только творительный. Однако отдельные примеры с винительным падежом встречаются в НКРЯ до 20-х гг. XIX в.: Я, посъдъвиій подъ илемомь старый воинъ, служащій 65 льть, имъвщій щзатіе предводительствовать россійское воинство къ побгдамъ, почитаю сію минуту драгоитьннтйшею наградою за труды мои (А.А. Бибиков. 1817). В НКРЯ встретился единственный пример конца XIX в., но не в значении 'руководить', а в значении 'направлять, идя впереди': - Да, только я их предводительствую в другую сторону, - смеясь, сказал Свияжский (Л.Н. Толстой. 1878).

В XVIII в. встречаются и примеры с дательным падежом, в основном в значении 'быть впереди': Каждый жеребеи предводительствует своему стаду кобыл, коих числом до 13 бывает (В.Ф. Зуев. 1785). Единичные примеры с дательным (также в значении 'быть впереди') находим и в середине XIX в.: Доклад гласит, что инсургенты выступили из Лучжоу, но Шу Син-га, предводительствуя храбрейшим войскам, сделал большой отпор и сильнейший урон инсургентов (К.А. Скачков. 1854).

Итак, винительный падеж был возможен до начала XIX в. Между тем пассивное причастие предводительствуемый отмечается в современных словарях [9], [11] и употребляется в текстах: Они или в толпе работяг, предводительствуемыле бригадиром (Сергей Довлатов. 1990).

Личные формы пассивного залога в современном языке не используются и в словарях не фиксируются. В НКРЯ нет примеров и более раннего времени, хотя, разумеется, это не говорит о том, что такие формы в принципе не употреблялись. Для более точных выводов нужны исследования дополнительных источников текстов. 


\section{Командовать}

Глагол командовать появился в русском языке во времена Петра I - в самом начале XVIII в. Он происходит от фр. commander через нем. commandieren и пол. komendrować. Первоначально внешний вид глагола был неустойчив, кроме кома́ндовать, использовались варианты: коммандовать, командровать, командоровать, командировать ${ }^{4}$ и др. с основными значениями 'быть командиром' ‘руководить', ‘управлять' ‘давать команду’ [14].

Этот глагол перестал управлять винительным уже в конце второй трети XVIII в., тогда как управление творительным было возможно с самого начала появления глагола в языке, т.е. с начала XVIII в. Показательны примеры из одного и того же текста с разным управлением - «Обстоятельная реляция» о Полтавской битве (1709): ...Левое жее крыло командовал его светлость князь Менииков, понеже тамо его пребытие потребнейте было; Генерала-маеора Шлипембаха, которой тем крылом командовал, 8 полон взяли.

Помимо винительного и творительного, глагол мог управлять и предложно-падежным сочетанием над + твор.: Морские же с сухопутныли в команде определяются следующим образом: кто с кем одного ранга, хотя и старее в чину, на море командовать морскому над сухопутным, а на земли сухопутному над морским (Петр I. 1722).

Причастие командуемый, как и в случаях с вышерассмотренными глаголами управлять, руководить и предводительствовать, сохраняется в языке. В НКРЯ за1803-1952 гг. находим 39 примеров, приведу три примера разных лет: Кутузов чрез своего лазутчика получил 1-го ноября известие, ставившее командуемую им армию почти в безвыходное положение (Л.Н. Толстой. 1867-1869); ...Было достаточно, чтобы командуемый мною полк бросился на штурм укрепленной позиции (П.Н. Краснов. 1922); И тут не только мы, славяне, но все «не немиь» чего-то не понимаем в этом германском тяготении к тому, чтобы быть управляемыми, быть командуемыми, быть под, а не над (Р.Б. Гуль. 1952).

С середины XX в. примеров с этим причастием в НКРЯ нет и само причастие считается несуществующим в русском языке: его нет ни в [9], ни в других словарях. Между тем в интернете масса примеров с этим официально не существующим словом, причём во вполне грамотных текстах, посвящённых военной тематике, например: 28 июля Южный фронт, командуемый до этого Родионом Малиновским - ещзе одним будущчим министром обороны - был расформирован, а его войска переданы новообразованному Северо-Кавказскому фронту под командованием маршала Буденного (сайт http://www.opoccuu.com/bitva-za-kavkaz.htm, 2013).

\footnotetext{
${ }^{4}$ В словаре [14] как омонимичный указан еще один глагол со значением 'послать, отправить куда-л. с заданием', возникший из тех же источников и имеющий примерно те же варианты, но вариант командова́mь с другим ударением. Этот второй глагол в современном языке сохранился в виде командировать.
} 
Личные формы пассива в настоящее время не употребляются, пример ХХ в. в НКРЯ встретился лишь один: Русские роть - непременная принадлежность каждой дивизии, как правило, командовались сербами, в то время как в итальянских бригадах были итальянские командиры (Б.А. Слуцкий. 1945). Но до конца ХІХ в., судя по примеру Рота командуется капитаном, приведённому в качестве иллюстрации в Толковом словаре Даля [15], такое употребление было вполне нормально.

\section{Заведовать / заведывать}

Наиболее старый вариант этого глагола - завъдать. В словаре [14] этот вариант со значением 'управлять, распоряжаться чем-л.' приводится как устаревший. Указана возможность двоякого управления: чем и что, что иллюстрируется двумя примерами начала XVIII в. Очевидно, глагол образован от переходного глагола въдать в значении 'управлять, править', который также представлен в словаре [14]. В НКРЯ примеров на глагол завъдать в рассматриваемом значении нет.

Более новый вариант глагола — завъдывать, в словаре [14] дан пример на завъдыьвать в переходном употреблении: Таврический торг, как и всть доходы Тавриды, он <Потемкин> единственно завъдывал (Державин). В НКРЯ глагол заведывать очень широко представлен, но только с начала XIX в. и вплоть до настоящего времени. Управление творительным падежом преобладает уже с самых первых примеров, хотя возможно и переходное употребление; характерно использование двоякого управления в одном и том же тексте: Первая экспедиция первого департамента заведывает все спорные и тяжебные дела; Вторая экспедиии заведывает всеми отраслями до финансов и внутреннего хозяйства относящимися (П.П. Свиньин. Описание Бессарабской области. 1816). Последний пример личной формы глагола в переходном употреблении фиксируется в НКРЯ в 1822 г., пассивное же причастие заведываемый употребляется вплоть до 30-х гг. ХХ в.: Нетопорчук - ютовый боиман «Генералиссимуса», его заведываемая часть - верхняя палуба от кормы до второй трубы со всем, что на ней находится (Л.С. Соболев. 1932).

Пример личной формы пассива в НКРЯ встретился лишь один: Городская полииия заведывается полиимейстером, в ведомстве коего состоят три частных пристава (П.П. Свиньин. 1816).

Глагол заведывать представлен как устаревший в словаре Ушакова, в более поздних словарях глагол не фиксируется, хотя с управлением творительным падежом употребляется до конца XX в., а формы действительныХ причастий встречаются и в XXI в.: Он рассказал и про низинку, и про табак, и еще про колхозную ферму, заведывать которой приставили никудылиного человека (Фазиль Искандер. 1989); А заведывал городком Цюрупы - из военных, всегда во френче и галифе, строгий, подтянутый, и везде во всём требовал порядка (А.И. Солженицын. 1993-1995); Бодро поднялась на пятый этаж и рассказала, что <... имеет и договор на перевод Рабле с Л.Б. Каменевым, заведывавшим в то время в Москве издатель- 
ством художественной литературы (Д.С. Лихачев. 1995). Понятно, что примеры принадлежат авторам, усвоившим нормы середины XX в., такое употребление можно считать затухающим, тем не менее до конца века оно еще возможно.

Всего в НКРЯ с 1809 по 1995 г. представлено 272 употребления глагола заведывать в личных формах; в форме действительных причастий (сюда же попадают и субстантивированные формы) 95 примеров XIX в. и 255 примеров XX-XXI вв. Страдательное причастие заведываемый встретилось в НКРЯ 15 раз с 1816 по 1932 г., а личная форма страдательного залога лишь раз в 1816 г.

С 1829 г. в текстах НКРЯ встречается вариант глагола заведовать, который постепенно вытесняет заведывать, страдательного причастия *заведуемый, естественно, никогда не было, ведь вариант заведовать появился в языке уже после того, как глагол заведывать утратил переходность, так что и новый вариант заведовать никогда не обладал переходностью.

В единичных случаях в XIX в. возможно было употребление глагола заведовать с управлением творительным падежом с предлогом над: Над несколькими мельницами заведовал один мельник, а мальчики сторожили ux (Ф.В. Булгарин. 1841).

\section{Помыкать}

В словаре [12] представлен переходный глагол помыкать в значении 'часто посылать, употреблять кого на посылки': Онъ безпрестанно ихъ помыкаemъ. В НКРЯ примеров в переходном употреблении нет, нет и примеров личных форм в пассивном залоге. С твор. падежом 276 употреблений, но до 1839 г. всего 3 примера. У меня не было никакого непосредственного начальника, а всякий помыкал мною по произволу (Ф.В. Булгарин. 1829).

Между тем примеры со страдательными причастиями в НКРЯ есть: два XIX в. и два XXI в.: Непрестанно помыкаемый Амуратом из земли в землю, то в Молдавию и Валахию, то в Венгрию <... хан вылолил у султана дозволение обмануть Россию ложным примирением... (Н.М. Карамзин. 1821-1823); ...Его герои, казалось, приглашали <...> к самопреодолению садо-мазохистской альтернативь: помыкать или быть помыкаемым (Давид Карапетян. 2000-2002).

\section{Править}

Глагол равить $^{5}$ в течение более чем двух веков употребляется в трёх основных значениях: 1) обладая властью, управлять' (править страной);

\footnotetext{
5 Здесь не рассматривается омонимичный глагол править (править корректуру, править лезвие), который не испытывал колебаний в управлении.
} 
2) 'направлять ход движения’ (править кораблем); 3) 'совершать, исполнять' (править молебен).

Что касается третьего значения, оно дается в словарях как устаревшее, в этом значении глагол был и остается переходным. В первых двух значениях в современном языке возможно лишь управление твор. падежом, однако в XVIII в. и вплоть до 40-х гг. XIX в. в обоих значениях возможно было двоякое управление: как винительным, так и творительным падежами. Приведу примеры из произведений А.С. Пушкина, в которых представлены разные варианты: 1) В тишине, / На руль склоняясь, наш кормщик умный / В молчаньи правил грузный чёлн (1827); Я был раздет и с усилием правил челноком против бурного течения (1836); 2) Да правлю я во славе свой народ, / Да буду благ и праведен, как ты (1824-1825); О боже мой, кто будет нами править? (1824-1825).

Примеры страдательного причастия правимый встречаются в корпусе с 1709 по 1833 г. Вот последние: ...nо струнам движенье робких рук, / Не правимых доверчивым искусством... (П.А. Плетнев. 1822); В самую суматоху боя Петр <..> остановляет на бегу судно, правимое к эскадре, $и$ оборачивает его назад (И.И. Лажечников. 1833). Примеры личных форм страдательного залога этого глагола встречаются в НКРЯ даже в более поздних текстах, чем страдательное причастие, вплоть до конца XIX в., например: C тех пор Иван надолго является совершенно безличным; русская держава правится не ияарем, а советом людей, окружающих ијаря (Н.И. Костомаров. 1862-1875).

Итак, мы рассмотрели историю грамматических изменений глаголов со значением управления с начала XVIII в. по настоящее время. Управление винительным падежом у всех рассмотренных глаголов сменилось управлением творительным, тем самым глаголы утратили переходность. Однако признаки переходности утрачивались постепенно. Сначала сменилось управление личных форм глаголов, при этом период вариативного управления винительным и творительным длился несколько десятков лет. Дольше в языке задерживается управление отглагольного существительного со значением действия, характерное для существительных от переходных глаголов, т.е. управление родительным падежом (это рассмотрено в статье на примере существительного управление от глагола управлять). Ещё дольше удерживается в языке личная форма пассивного залога. Наконец, самой «живучей» формой переходных глаголов оказывается пассивное причастие. Оно может продолжать употребляться десятки и даже сотни лет после утраты переходности личными формами глагола. Именно в такой последовательности происходят изменения у всех глаголов, различаются лишь временные рамки. Полученные данные представлены в приводимой ниже таблице. Разумеется, данные о времени происходивших изменений можно считать приблизительными: ведь если примеры в НКРЯ встречаются, можно однозначно сказать, что такое употребление было, а если не встречаются, из этого еще со стопроцентной вероятностью не следует, что реально в языке таких употреблений не было. 


\begin{tabular}{|c|c|c|c|c|c|c|}
\hline Глаголы & $\begin{array}{l}\text { Управле- } \\
\text { ние вин. } \\
\text { падежом }\end{array}$ & $\begin{array}{l}\text { Управле- } \\
\text { ние твор. } \\
\text { падежом }\end{array}$ & \begin{tabular}{|c} 
Период \\
существо- \\
вания ва- \\
риативного \\
управления
\end{tabular} & $\begin{array}{c}\text { Наличие } \\
\text { личных } \\
\text { форм пасси- } \\
\text { ва, отраже- } \\
\text { ние в совр. } \\
\text { словарях }\end{array}$ & $\begin{array}{c}\text { Наличие } \\
\text { пассивного } \\
\text { причастия, } \\
\text { отражение в } \\
\text { совр. слова- } \\
\text { рях }\end{array}$ & $\begin{array}{c}\text { Период } \\
\text { между } \\
\text { утратой } \\
\text { переходно- } \\
\text { сти и утра- } \\
\text { той пасс. } \\
\text { причастия }\end{array}$ \\
\hline управлять & $\begin{array}{c}\text { До начала } \\
\text { XIX в. }\end{array}$ & $\begin{array}{c}\text { первый } \\
\text { пример - } \\
1709 \text { г. }\end{array}$ & 100 лет & $\stackrel{+}{+}$ & $\stackrel{+}{+}$ & $\begin{array}{c}>200 \text { лет } \\
\ldots\end{array}$ \\
\hline руководить & $\begin{array}{c}\text { До конца } \\
\text { XIX в. }\end{array}$ & $\begin{array}{c}\text { С начала } \\
\text { XIX в. }\end{array}$ & 100 лет & $\begin{array}{c}\text { До конца } \\
30-\text { - гг. } \\
\text { XX в. [11] }\end{array}$ & $\stackrel{+}{[9,11]}$ & 120 лет ... \\
\hline $\begin{array}{l}\text { предводи- } \\
\text { тельство- } \\
\text { вать }\end{array}$ & $\begin{array}{c}\text { До начала } \\
\text { XIX в. }\end{array}$ & $\begin{array}{c}\text { C 60-х гг. } \\
\text { XVIII в. }\end{array}$ & 50 лет & $\begin{array}{c}\text { В НКРЯ } \\
\text { примеров } \\
\text { нет }\end{array}$ & $\stackrel{+}{+}+$ & 200 лет ... \\
\hline $\begin{array}{l}\text { командо- } \\
\text { вать }\end{array}$ & $\begin{array}{l}\text { До 70-х гг. } \\
\text { XVIII в. }\end{array}$ & $\begin{array}{l}\text { C начала } \\
\text { XVIII в. }\end{array}$ & 65 лет & $\begin{array}{c}\text { До конца } \\
\text { XIX в. }\end{array}$ & $\begin{array}{c}\text { + в спец. } \\
\text { текстах } \\
\text { В совр. сло- } \\
\text { варях не } \\
\text { фиксируется }\end{array}$ & $\begin{array}{c}180 \text { лет в } \\
\text { литератур- } \\
\text { ном языке } \\
+ \\
70 \text { лет в } \\
\text { спец. } \\
\text { текстах ... }\end{array}$ \\
\hline заведывать & До 1822 г. & $\begin{array}{c}\text { С начала } \\
\text { XIX в. } \\
\text { до конца } \\
\text { XX в. }\end{array}$ & $\begin{array}{l}\text { Более } \\
20 \text { лет }\end{array}$ & $\begin{array}{c}\text { В НКРЯ } \\
\text { один пример } \\
1816 \text { г. }\end{array}$ & $\begin{array}{c}\text { До 30-х гг. } \\
\text { ХХ в. } \\
\text { В словарях } \\
\text { не фиксиру- } \\
\text { ется }\end{array}$ & 100 лет \\
\hline заведовать & - & C 1829 г. & - & - & - & - \\
\hline помыкать & XVIII в. & $\begin{array}{c}\text { С начала } \\
\text { XIX в. }\end{array}$ & $?$ & $\begin{array}{c}\text { В НКРЯ } \\
\text { примеров } \\
\text { нет } \\
\end{array}$ & $\begin{array}{c}\text { Редко, } \\
\text { вПлоть } \\
\text { до наст. вр. } \\
\end{array}$ & > 200 лет \\
\hline $\begin{array}{l}\text { править } \\
\text { (1-е и 2-е } \\
\text { знач.) }\end{array}$ & $\begin{array}{c}\text { До 40-х гг. } \\
\text { XIX в. }\end{array}$ & $\begin{array}{c}\text { С середи- } \\
\text { ны } \\
\text { XVIII в. }\end{array}$ & 90 лет & $\begin{array}{c}\text { До конца } \\
\text { XIX в. }\end{array}$ & $\begin{array}{c}1709- \\
1833 \text { гг. }\end{array}$ & $\begin{array}{c}\text { Период } \\
\text { между } \\
\text { утратой } \\
\text { переходно- } \\
\text { сти и утра- } \\
\text { той пасси- } \\
\text { ва }-50 \text { лет }\end{array}$ \\
\hline
\end{tabular}

\section{Литература}

1. Белошапкова B.A. Изменения в субстантивных словосочетаниях // Очерки по исторической грамматике русского литературного языка XIX века: Изменения в системе словосочетаний в русском литературном языке XIX века. М., 1964. С. 128-220.

2. Крысько В.Б. Исторический синтаксис русского языка: Объект и переходность. 2-е изд., испр. и доп. М. : Азбуковник, 2006. 486 с.

${ }^{6}$ Многоточие здесь означает, что период не завершен, причастие используется вплоть до настоящего времени.

${ }^{7}$ Глагол править, в отличие от остальных рассматриваемых глаголов, раньше утратил форму пассивного причастия, чем личные формы пассивного залога 
3. Ломтев Т.П. Очерки по историческому синтаксису русского языка. М. : Изд-во МГУ, 1956. $506 \mathrm{c.}$

4. Национальный корпус русского языка. URL: www.ruscorpora.ru

5. Буслаев Ф.И. Опыт исторической грамматики русского языка : учеб. пособие для преподавателей. Ч. 2: Синтаксис. М., 1858.

6. Булаховский Л.А. Русский литературный язык первой половины XIX века: Фонетика. Морфология. Ударение. Синтаксис. М. : Учпедгиз, 1954. 468 с.

7. Филиппова В.M. Вариантные глагольно-именные словосочетания в русском литературном языке XIX века (материалы и наблюдения) // Материалы и исследования по истории русского литературного языка. М., 1957. С. 166-217.

8. Виноградов В.В. Очерки по истории русского литературного языка XVIIXIX веков. 3-е изд. М. : Высш. шк., 1982. 528 с.

9. Зализняк А.А. Грамматический словарь русского языка: Словоизменение. 4-е изд., испр. и доп. М. : Рус. слов., 2003. 800 с.

10. Словарь русского языка : в 4 т. / АН СССР, Ин-т рус. яз. ; под ред. А.П. Евгеньевой. 2-е изд., испр. и доп. М. : Рус. яз., 1981.

11. Толковый словарь русского языка : в 4 т. / под ред. Д.Н. Ушакова. М. : ОГИЗ, $1935-1940$.

12. Словарь Академии Российской, по азбучному порядку расположенный. СПб., 1806-1822. T. 1-6.

13. Словарь языка Пушкина : в 4 т. / отв. ред. В.В. Виноградов. 2-е изд., доп. М. : Азбуковник, 2000. долж.)

14. Словарь русского языка XVIII в. Л. ; СПб., 1984-2017. Вып. 1-21. (Изд. про-

15. Даль В.И. Толковый словарь живаго великорускаго языка : в 4 т. 2-е изд., испр. и доп. СПб. ; М., 1880-1882.

\section{ON THE GRADUAL LOSS OF TRANSITIVITY: VERBS OF AUTHORITY}

Vestnik Tomskogo gosudarstvennogo universiteta. Filologiya - Tomsk State University Journal of Philology. 2018. 51. 31-46. DOI: 10.17223/19986645/51/4

Elena V. Muravenko, Russian State University for the Humanities (Moscow, Russian Federation). E-mail: emuravenko@yandex.ru

Keywords: verbs of authority, change in case-governing properties, transitivity, loss of transitivity, passive voice, passive construction, passive participle, accusative case, instrumental case.

Over time, case-governing properties of individual verbs can undergo change, and in some instances this change can be accompanied with shifts in the transitivity. This paper presents and analyzes changes in the case-governing properties of several verbs that used to take the object in the accusative but then switched to objects in the instrumental. As these verbs moved away from taking accusative objects, they also gradually shifted from fully transitive to intransitive. The diachronic evolution of these verbs thus illustrates a close link between morphological and syntactic changes.

The verbs under discussion have the unifying general meaning of exerting authority, and the author will refer to them as verbs of authority. They include the following lexical units (shown in the infinitive): upravlyat' 'reign, govern, rule, command'; rukovodit' 'govern, control, direct'; predvoditel 'stvovat' 'preside, lead, guide, oversee'; komandovat' 'command, be in charge'; zavedovat' 'manage, direct'; pomykat' 'maltreat', and pravit' 'reign, govern, rule'. As data from the late 18th century show, all these verbs used to take an accusative object, but over the last three centuries, this accusative object was replaced with the object in the instrumental case. As a result, verbs of authority were losing their transitive properties. The loss of transitivity was gradual, with varying pace across different constructions. The change started with finite forms of verbs of authority, and over several decades, the case of 
objects taken by these verbs varied between the accusative and the instrumental. The new pattern then spread to event nominalizations. In general, Russian event nominalizations formed from transitive verbs take the object in the genitive case. Nominalizations formed from verbs of authority retained genitive objects well after finite forms switched to taking the instrumental, but eventually the genitive was replaced by the instrumental in event nominalizations as well. Finite passive forms of verbs of authority were retained even longer, but those were eventually lost as well. Finally, long after the change in these three constructions, passive participles of verbs of authority remained productive. The order of change finite form $>$ nominalization $>$ passive $>$ passive participle is constant across all the verbs of this class, and the only difference appears to be in the timing of a particular change for a given verb.

Data from the Russian National Corpus (www.ruscorpora.ru) support a conclusion that if at some point over the last 300 years a currently intransitive verb formed a passive participle the verb must have been transitive one or two centuries ago. To illustrate, the Contemporary Standard Russian (CSR) has the passive participle upravlyayemyy 'governed' whereas the corresponding verb upravlyat' is no longer transitive. Until the beginning of the 19th century, this verb was transitive and took the object in the accusative (cf. upravlyat' voysko 'command an army'). The event nominalization upravlenie 'administration, government' retained transitivity for another thirty-odd years after the finite forms switched to taking the instrumental (e.g., upravlenie imeniy-a 'administering the estate-GEN'); however, in CSR the object in the nominalization also has to appear in the instrumental (upravlenie imeniy-em). As a result, we find a passive participle corresponding to an intransitive verb for over a couple centuries. Since intransitive verbs in CSR do not form passive participles it is more accurate to analyze the verb and the participle as parallel, independent forms, with the participle testifying to the long-lost transitivity of upravlyat'.

The grammatical changes discussed in this paper are represented in three tables that track different transitivity characteristics of verbs of authority over time.

\section{References}

1. Beloshapkova, V.A. (1964) Izmeneniya v substantivnykh slovosochetaniyakh [Changes in substantive phrases]. In: Vinogradov, V.V. \& Shvedova, N.Yu. (eds) Ocherki po istoricheskoy grammatike russkogo literaturnogo yazyka XIX veka: Izmeneniya v sisteme slovosochetaniy $v$ russkom literaturnom yazyke XIX veka [Essays on the historical grammar of the Russian literary language of the 19th century: Changes in the system of word combinations in the Russian literary language of the 19th century]. Moscow: Nauka

2. Krys'ko, V.B. (2006) Istoricheskiy sintaksis russkogo yazyka: Ob"'ekt i perekhodnost' [Historical syntax of the Russian language: Object and transitivity]. 2nd ed. Moscow: Azbukovnik.

3. Lomtev, T.P. (1956) Ocherki po istoricheskomu sintaksisu russkogo yazyka [Essays on the historical syntax of the Russian language]. Moscow: Moscow State University.

4. National Corpus of the Russian language. [Online] Available from: www.ruscorpora.ru (In Russian).

5. Buslaev, F.I. (1858) Opyt istoricheskoy grammatiki russkogo yazyka [Experience of the historical grammar of the Russian language]. Pt. 2. Moscow: Univ. tip.

6. : Bulakhovskiy, L.A. (1954) Russkiy literaturnyy yazyk pervoy poloviny XIX veka: Fonetika. Morfologiya. Udarenie. Sintaksis [Russian literary language of the first half of the 19th century: Phonetics. Morphology. Stress. Syntax]. Moscow: Uchpedgiz.

7. Filippova, V.M. (1957) Variantnye glagol'no-imennye slovosochetaniya v russkom literaturnom yazyke XIX veka (materialy i nablyudeniya) [Variant verbal-nominal word combinations in the Russian literary language of the 19th century (materials and 
observations)]. In: Materialy $i$ issledovaniya po istorii russkogo literaturnogo yazyka [Materials and research on the history of the Russian literary language]. Moscow: USSR AS.

8. Vinogradov, V.V. (1982) Ocherki po istorii russkogo literaturnogo yazyka XVII$X I X$ vekov [Essays on the history of the Russian literary language of the 17th-19th centuries]. 3rd ed. Moscow: Vysshaya shkola.

9. Zaliznyak, A.A. (2003) Grammaticheskiy slovar' russkogo yazyka: Slovoizmenenie [Grammatical dictionary of the Russian language: inflections]. 4th ed. Moscow: Rus. slov.

10. Evgen'eva, A.P. (ed.) (1981) Slovar' russkogo yazyka: $v 4 t$. [Dictionary of the Russian language: in 4 vols]. 2nd ed. Moscow: Rus. yaz.

11. Ushakov, D.N. (ed.) (1935-1940) Tolkovyy slovar' russkogo yazyka: $v \quad 4 \quad t$. [Explanatory dictionary of the Russian language: in 4 vols]. Moscow: OGIZ.

12. Anon. (1806-1822) Slovar' Akademii Rossiyskoy, po azbuchnomu poryadku raspolozhennyy [Dictionary of the Russian Academy, in alphabetical order]. Vols 1-6. St. Petersburg: [s.n.].

13. Vinogradov, V.V. (ed.) (2000) Slovar' yazyka Pushkina: v 4 t. [Dictionary of the language of Pushkin: in 4 vols]. 2nd ed. Moscow: Azbukovnik.

14. Sorokin, Yu.S. et al. (eds) (1984-cont.) Slovar' russkogo yazyka XVIII v. [Dictionary of the Russian language of the 18th century]. Vols 1-21. Leningrad; St. Petersburg: Nauka.

15. Dahl, V.I. (1880-1882) Tolkovyy slovar' zhivago velikoruskago yazyka: $v 4 t$. [Explanatory Dictionary of the Living Great Russian language: in 4 vols]. 2nd ed. St. Petersburg; Moscow. 